\title{
Penyelesaian Sengketa Konsumen Melalui Badan Penyelesaian Sengketa Konsumen (BPSK) Kota Serang
}

\author{
Arif Rahman \\ Sekolah Tinggi Keguruan dan Ilmu Pendidikan (STKIP) Pelita Pratama, Serang. \\ email: rahmanarifhak@gmail.com
}

\begin{abstract}
Consumer Dispute Settlement Board (BPSK), as mentioned in the Rules No. 8 Years 1999 about Consumer Protection (UUPK) which is formed by the government, is the institution that responsible for holding and resolving disputes between consumers and businesses. BPSK formation is intended to overcome the vagaries of litigation that tends to have long, formal and convoluted process with the alternative dispute resolution outside the court that is based on the principle of fast, simple and low cost. This research is using normative juridical approach. The author conducted a review of literature regarding consumer protection law and the settlement of consumer disputes according to consumer protection codes which were collected and classified by the record in detail, systematic and focused on literature. Furthermore, the author conducted a descriptive analysis of data, in order to obtain a complete overview of the issues regarding the settlement of consumer disputes at BPSK Kota Serang. The Results of this research conducted by the author suggest a role of BPSK Serang in solving consumer disputes according to the Law No. 8 of 1999 on Consumer Protection can be resolved in three ways, which are conciliation, mediation and arbitration on the basis of selection and consent of the parties to the dispute. Verdict forms of conciliation methods and mediation are final and binding, without having to request fiat execution to the local court, while the form of the decision taken by arbitration method has to be requested fiat execution to the local Court for the arbitration award to have the executorial power.
\end{abstract}

Keywords: Consumer Dispute Settlement Board, The Consumer Dispute, Settlement of Consumer Disputes, Consumer Protection

\begin{abstract}
Abstrak
Badan Penyelesaian Sengketa Konsumen (BPSK) sebagaimana disebutkan dalam UndangUndang No. 8 Tahun 1999 tentang Perlindungan Konsumen (UUPK) yang dibentuk oleh pemerintah, adalah badan yang bertugas menangani dan menyelesaikan sengketa antara konsumen dan pelaku usaha. Pembentukan BPSK ini ditujukan untuk mengatasi liku-liku proses pengadilan yang cenderung lama, formal dan berbelit-belit dengan jalan alternatif penyelesaian sengketa di luar pengadilan berdasarkan asas cepat, sederhana dan biaya murah. Penelitian ini dilakukan pada Badan Penyelesaian Sengketa Konsumen yang berkedudukan di Kota Serang dengan menggunakan jenis dan pendekatan yuridis normatif. Penulis melakukan penelaahan literatur hukum seputar perlindungan konsumen serta penyelesaian sengketa konsumen terhadap undang-undang perlindungan konsumen yang kemudian dikumpulkan dan klasifikasikan dengan catatan secara rinci, sistematis dan terarah mengenai dokumen/kepustakaan. Selanjutnya penulis melakukan analisa data secara deskriptif, sehingga diperoleh gambaran yang menyeluruh tentang permasalahanpermasalahan seputar penyelesaian sengketa konsumen di BPSK Kota Serang. Hasil dari penelitian yang penulis lakukan ini mengemukakan peran BPSK Kota Serang dalam upaya penyelesaian sengketa konsumen ditinjau berdasarkan Undang-Undang No 8 Tahun 1999 tentang Perlindungan Konsumen dapat ditempuh dengan 3 (tiga) metode/cara yaitu, konsiliasi, mediasi dan arbitrase atas dasar pilihan dan persetujuan para pihak yang bersengketa. Bentuk putusan dengan metode konsiliasi dan mediasi bersifat final dan mengikat, tanpa harus dimintakan fiat eksekusi ke Pengadilan Negeri
\end{abstract}


setempat, sedangkan bentuk putusan yang ditempuh dengan metode arbitrase harus dimintakan fiat eksekusi ke Pengadilan Negeri setempat agar putusan arbitrase tersebut mempunyai kekuatan eksekutorial.

Kata Kunci: Badan Penyelesaian Sengketa Konsumen, Sengketa Konsumen, Penyelesaian Sengketa Konsumen, Perlindungan Konsumen.

\section{PENDAHULUAN}

Dampak pembangunan nasional berpengaruh terhadap perkembangan perekonomian nasional telah menghasilkan variasi produk barang dan/atau jasa yang dapat dikonsumsi. Kemajuan di bidang ilmu pengetahuan, teknologi dan telekomunikasi dan informatika juga turut mendukung perluasan ruang gerak transaksi barang dan/atau jasa yang diinginkan dapat terpenuhi serta semakin terbuka lebar kebebasan untuk memilih aneka jenis kualitas barang dan/atau jasa sesuai kemampuannya.

Masyarakat luas sebagai konsumen sudah seharusnya diberikan perlindungan karena seringkali tidak berdaya dalam menghadapi kegiatan perdagangan sehari-hari. Permasalahan yang dihadapi konsumen Indonesia, seperti juga yang dialami di negaranegara berkembang lainnya, tidak hanya sekedar memilih barang, tetapi jauh lebih kompleks dari itu menyangkut pada penyadaran semua pihak, baik itu pengusaha, pemerintah maupun konsumen sendiri tentang pentingnya perlindungan konsumen. ${ }^{1}$

Kedudukan konsumen pada umumnya masih lemah dalam bidang ekonomi, pendidikan dan daya tawar, karena itu sangatlah dibutuhkan adanya undang-undang yang melindungi kepentingan-kepentingan konsumen. ${ }^{2}$ Untuk dapat memberikan jaminan pada penyelenggaraan perlindungan konsumen, maka pemerintah menuangkan perlindungan konsumen dalam suatu produk hukum. Hal ini penting karena hanya hukum

1 AZ. Nasution, Hukum Perlindungan Konsumen: Suatu Pengantar, Cetakan Keempat, (Jakarta: Diadit Medika, 2011), hal 8.

2 Susanti Agung Nugroho, Proses Penyelesaian Sengketa Konsumen Ditinjau dari Hukum Acara Serta Kendala Implementasinya, (Jakarta: Kencana, 2008), hal 2. yang memiliki kekuatan memaksa pelaku usaha untuk menaatinya, dan juga hukum memiliki sanksi yang tegas. Perlindungan konsumen adalah segala upaya yang menjamin adanya kepastian hukum untuk memberikan perlindungan kepada konsumen. ${ }^{3}$ Kepastian hukum itu meliputi segala upaya untuk memberdayakan konsumen memperoleh atau menentukan pilihannya atas barang dan/atau jasa kebutuhannya serta mempertahankan atau membela hak-haknya apabila dirugikan oleh perilaku pelaku usaha penyedia kebutuhan konsumen tersebut. $^{4}$

$$
\text { Undang-Undang Perlindungan }
$$

Konsumen Ini memang sengaja dibentuk dengan beberapa pertimbangan antara lain karena ketentuan hukum yang melindungi kepentingan konsumen di Indonesia belum memadai, sehingga perlu adanya perangkat peraturan perundang-undangan untuk mewujudkan keseimbangan perlindungan kepentingan konsumen dan pelaku usaha demi terciptanya perekonomian yang sehat. Selain itu, dalam era globalisasi, pembangunan perekonomian nasional harus dapat mendukung tumbuhnya dunia usaha sehingga mampu menghasilkan beraneka barang

3 Republik Indonesia, Undang-Undang No. 8 Tahun 1999 tentang Perlindungan Konsumen, Pasal 1 angka 1

4 Az Nasution, Aspek Hukum Perlindungan Konsumen, Jumal Teropong, (Mei 2003, Masyarakat Pemantau Peradilan Indonesia), hal 67. 
dan/atau jasa yang dapat meningkatkan kesejahteraan masyarakat banyak. ${ }^{5}$

Undang-Undang Perlindungan

Konsumen (UUPK) pada hakikatnya telah memberikan kesetaraan kedudukan konsumen dengan pelaku usaha, tetapi konsep perlindungan konsumen sebagai suatu kebutuhan harus senantiasa disosialisasikan untuk menciptakan hubungan konsumen dengan pelaku usaha dengan prinsip kesetaraan yang berkeadilan, dan untuk mengimbangi kegiatan pelaku usaha yang menjalankan prinsip ekonomi untuk mendapat keuntungan yang semaksimal mungkin dengan modal seminimal mungkin, yang dapat merugikan kepentingan konsumen, langsung maupun tidak langsung. ${ }^{6}$

Untuk mengatasi liku-liku proses pengadilan yang lama dan formal UUPK memberikan jalan alternatif dengan menyediakan penyelesaian sengketa di luar pengadilan (non-litigasi) melalui konsiliasi, mediasi dan arbitrase. ${ }^{7}$ Penyelesaian sengketa konsumen di luar pengadilan diselenggarakan untuk mencapai kesepakatan mengenai bentuk dan besarnya ganti kerugian, dan/atau mengenai tindakan tertentu untuk menjamin tidak akan terjadi kembali kerugian yang diderita konsumen. Dengan diundangkannya UUPK, maka masyarakat/konsumen yang dirugikan merasa terlindungi, dan mempunyai pilihan untuk mengadukan permasalahannya dengan mengajukan gugatan ke pengadilan negeri, dengan proses beracara yang lebih lama atau dapat mengadukan kepada Badan Penyelesaian Sengketa Konsumen (BPSK).

BPSK sebagaimana disebutkan dalam UUPK, yang dibentuk oleh pemerintah, adalah badan yang bertugas menangani dan menyelesaikan sengketa antara pelaku usaha dan konsumen, tetapi bukanlah merupakan bagian dari institusi kekuasaan kehakiman. Konsep dasar pembentukan lembaga BPSK ini adalah untuk menangani penyelesaian sengketa antara konsumen dan pelaku usaha.

5 Gunawan Widjaya dan Ahmad Yani, Hukum Tentang Perlindungan Konsumen, (Jakarta: Pustaka Gramedia Utama), 2003, hal 98.
Penyelesaian sengketa konsumen di Badan Penyelesaian Sengketa Konsumen pada prinsipnya diserahkan kepada pilihan para pihak konsumen dan pelaku usaha yang bersangkutan apakah akan diselesaikan melalui konsiliasi, mediasi atau arbitrase.

Putusan BPSK sebagai hasil dari penyelesaian sengketa konsumen secara konsiliasi, mediasi atau arbitrase, bersifat final dan mengikat. Ketentuan final dan mengikat ini sebagaimana tercantum pada Pasal 54 Ayat (3) UUPK yang menyatakan "Putusan Majelis BPSK bersifat final dan mengikat". Pengertian final berarti bahwa penyelesaian sengketa ini telah selesai dan berakhir. Sedangkan kata mengikat mengandung arti memaksa dan sebagai sesuatu yang harus dijalankan oleh pihak yang diwajibkan untuk itu.

Maka atas dasar latar belakang masalah yang diuraikan di atas, penulis bertujuan melakukan penelitian dengan judul "Penyelesaian Sengketa Konsumen Melalui Badan Penyelesaian Sengketa Konsumen (BPSK) Berdasarkan Undang-Undang No. 8 Tahun 1999 tentang Perlindungan Konsumen (Studi Kasus di BPSK Kota Serang)".

\section{METODE PENELITIAN}

Jenis dan pendekatan penelitian yang digunakan adalah penelitian yuridis normatif, yaitu hukum dikonsepsi sebagai norma, kaidah, asas atau dogma-dogma dengan pendekatan penelitian melalui studi kepustakaan yaitu dengan melakukan penelahaan terhadap bahan pustaka/literatur yang berkaitan seputar perlindungan konsumen serta penyelesaian sengketa konsumen yang ditempuh di luar pengadilan khususnya penyelesaian sengketa melalui Badan Penyelesaian Sengketa (BPSK). Dalam penelitian ini analisa data dilakukan secara kualitatif normatif yakni analisa yang dipakai tanpa menggunakan angka maupun rumusan statistika dan matematika artinya

Susanti Agung, Op.Cit, hal 12.

Ibid., hal. 13. 
disajikan dalam bentuk uraian. Dimana hasil analisis akan dipaparkan secara deskriptif, dengan harapan dapat menggambarkan secara jelas mengenai proses hukum penyelesaian sengketa konsumen melalui Badan Penyelesaian Sengketa Konsumen, sehingga diperoleh gambaran yang menyeluruh tentang permasalahan-permasalahan yang diteliti.

\section{PEMBAHASAN}

\section{Perlindungan Konsumen}

Perlindungan hukum bagi konsumen adalah suatu masalah yang besar, dengan persaingan global yang terus berkembang. Perlindungan hukum sangat dibutuhkan dalam persaingan dan banyaknya produk dan layanan yang menempatkan konsumen dalam posisi tawar yang lemah. Perlindungan hukum bagi konsumen dalam bentuk perlindungan hukum yang diberikan oleh negara.

Pentingnya suatu negara mengatur perlindungan hukum terhadap konsumen, umumnya didasarkan pada pertimbangan aktualitas dan urgensinya. Dalam pertimbangan aktualitasnya perlindungan hukum bagi konsumen perlu ditegakkan pada sebuah pemerintahan berdasarkan rumusan situasi yang sedang dan akan berkembang terhadap nasib masyarakat konsumen. Hal ini penting karena hanya hukum yang dapat memiliki kekuatan untuk memaksa pelaku usaha untuk menaatinya, dan juga hukum memiliki sanksi yang tegas. Mengingat dampak penting yang dapat ditimbulkan akibat tindakan pelaku usaha yang sewenang-wenang dan hanya mengutamakan kepentingan bisnisnya dari bisnisnya sendiri, maka pemerintah memiliki kewajiban untuk melindungi konsumen yang posisinya memang lemah. Maka adtas dasar itu, pertimbangan penegakan perlindungan konsumen ini biasanya ditempuh dengan memperhatikan ${ }^{8}$ :

a. Tingkat pembangunan masing-masing negara;

8 Aman Sinaga, Pemberdayaan Hak-Hak Konsumen di Indonesia. (Jakarta: Direktorat Perlindungan Konsumen DITJEN Perdagangan dalam Negeri b. Pertumbuhan industri dan teknologi;

c. Filosofi dan kebijakan pembangunan.

Dalam memberikan perlindungan hukum bagi konsumen dengan cara intervensi negara untuk melindungi hak-hak konsumen dalam bentuk peraturan perundang-undangan. Terhadap posisi tawar yang lemah tersebut, maka ia harus dilindungi oleh hukum. Hal itu dikarenakan salah satu sifat dan tujuan hukum adalah memberikan perlindungan kepada masyarakat. Perlindungan hukum kepada masyarakat tersebut harus diwujudkan dalam bentuk kepastian hukum yang menjadi hak konsumen.

\section{Dasar Hukum Perlindungan Konsumen}

Hukum perlindungan konsumen selalu berhubungan dengan berbagai bidang dan cabang hukum lain, karena pada tiap bidang dan cabang hukum itu senantiasa terdapat pihak yang berpredikat sebagai "konsumen". Oleh karena itu, ruang lingkup hukum perlindungan konsumen sulit dibatasi hanya dengan menampungnya dalam satu jenis undang-undang yaitu Undang-Undang Perlindungan Konsumen (UUPK). Memahami antara hukum konsumen dan hukum perlindungan konsumen dan keterkaitan antara hak-hak pokok dari konsumen dan keterkaitan antara hukum perlindungan konsumen dengan bidang-bidang hukum yang lain dapat memberikan gambaran menyeluruh tentang hukum perlindungan konsumen.

Undang-Undang No. 8 Tahun 1999 tentang Perlindungan Konsumen tidak memuat definisi mengenai hukum perlindungan konsumen tetapi memuat perumusan mengenai perlindungan konsumen yaitu sebagai "segala upaya yang menjamin adanya kepastian hukum untuk memberikan perlindungan kepada konsumen."

Perlindungan Hukum bagi konsumen adalah dengan melindungi hak-hak konsumen. Walaupun sangat beragam, secara garis besar

Departemen Perindustrian dan Perdagangan Bekerjasama dengan Yayasan Gemainti, 2001), hal. 21 . 
hak-hak konsumen dapat dibagi dalam tiga hak yang dapat menjadi prinsip dasar yaitu'

1) Hak yang dimaksudkan untuk mencegah konsumen dari kerugian, baik kerugian personal, maupun kerugian harta kekayaan;

2) Hak untuk memperoleh barang atau jasa dengan harga yang wajar;

3) Hak untuk memperoleh penyelesaian yang patut terhadap permasalahan yang dihadapi.

Apabila Konsumen benar-benar akan dilindungi, maka hak-hak konsumen harus dipenuhi, baik oleh negara maupun oleh pelaku usaha, karena pemenuhan hak-hak konsumen tersebut akan melindungi kerugian konsumen dari berbagai aspek. Dalam pasal 2 UUPK, dinyatakan bahwa perlindungan hukum bagi konsumen diselenggarakan sebagai usaha bersama berdasarkan 5 (lima) prinsip dalam pembangunan nasional, yaitu:

1) Prinsip manfaat. Dimaksudkan untuk mengamanatkan bahwa segala upaya dalam penyelenggaraan perlindungan konsumen harus memberi manfaat sebesar-besarnya bagi kepentingan konsumen dan pelaku usaha secara keseluruhan;

2) Prinsip keadilan, dimaksudkan agar partisipasi seluruh rakyat dapat diwujudkan secara maksimal dan memberikan kesempatan kepada konsumen dan pelaku usaha untuk memperoleh haknya dan melaksanakan kewajibannya secara adil;

3) Prinsip keseimbangan, dimaksudkan untuk memberikan keseimbangan antara kepentingan konsumen, pelaku usaha dan pemerintah;

4) Prinsip keamanan dan keselamatan konsumen, dimaksudkan untuk memberi jaminan atas keamanan dan keselamatan kepada konsumen dalam

Ahmadi Miru, Prinsip-Prinsip Perlindungan Hukum Bagi Konsumen di Indonesia, Disertasi Program Pascasarjana Universitas Airlangga, (Surabaya, 2000), hal. 140. Dalam Halim Barakatullah, Op.Cit., hal. 25. penggunaan, pemakaian dan pemanfaatan barang dan/atau jasa yang digunakan;

5) Prinsip kepastian hukum, dimaksudkan agar baik pelaku usaha maupun konsumen menaati hukum dan memperoleh keadilan dalam penyelenggaraan perlindungan hukum bagi konsumen, di mana negara dalam hal ini turut menjamin adanya kepastian hukum tersebut.

Kelima asas yang disebutkan tersebut bila diperhatikan substansinya, dapat dibagi menjadi 3 asas yaitu:

1) Asas kemanfaatan yang di dalamnya meliputi asas keamanan dan keselamatan;

2) Asas keadilan yang di dalamnya meliputi asas keseimbangan dan

3) Asas kepastian hukum.

Melalui ketiga substansi tersebut, terdapat komitmen untuk mewujudkan tujuan perlindungan konsumen, yaitu ${ }^{10}$ :

1) Meningkatkan kesadaran, kemampuan dan kemandirian konsumen untuk melindungi diri;

2) Mengangkat harkat dan martabat konsumen dengan cara menghindarkannya dari ekses negatif pemakaian barang atau jasa;

3) Meningkatkan pemberdayaan konsumen dalam memilih, menentukan dan menuntut hak-haknya sebagai konsumen;

4) Menciptakan sistem perlindungan konsumen yang mengandung unsur kepastian hukum dan keterbukaan informasi serta akses untuk mendapatkan informasi;

5) Menumbuhkan kesadaran pelaku usaha mengenai pentingnya perlindungan konsumen sehingga tumbuh sikap yang

10 Yusuf Shofie, Pelaku Usaha, Konsumen dan Tindak Pidana Korporasi, (Jakarta: Ghalia Indonesia, 2002), hal. 31. 
jujur dan bertanggung jawab dalam berusaha;

6) Meningkatkan kualitas barang atau jasa yang menjamin kelangsungan usaha produksi barang atau jasa, kesehatan, kenyamanan dan keselamatan konsumen.

Adapun mengenai ketentuan yang mengatur tentang pencantuman klausula baku sebagaimana yang diatur dalam pasal 18 UUPK, memberikan andil terhadap perlindungan konsumen. Dalam penjelasan pasal 18 ayat (1) UUPK ditegaskan bahwa adanya larangan pencantuman klausula baku untuk menempatkan kedudukan konsumen setara dengan pelaku usaha berdasarkan prinsip kebebasan berkontrak.

Sebagai bagian dari hukum nasional, UUPK membuka kemungkinan pemberlakuan hukum konsumen berdasarkan ketentuan peralihan:

\section{"Segala ketentuan peraturan perundang-undangan yang bertujuan melindungi konsumen yang telah ada pada saat undang-undang ini diundangkan, dinyatakan tetap berlaku sepanjang tidak diatur secara khusus dan/atau tidak bertentangan dengan undang- undang ini.' 11}

Ketentuan ini sebagai penegasan bahwa UUPK merupakan ketentuan khusus (lex specialis) terhadap ketentuan peraturan perundang-undangan yang sudah ada sebelum ada UUPK, sesuai dengan asas lex specialis derogat legi generalis. Yang artinya ketentuan di luar UUPK tetap berlaku sepanjang tidak diatur secara khusus dalam UUPK dan/atau tidak bertentangan dengan UUPK. Kendati hukum perlindungan konsumen dalam banyak aspek erat kaitannya dengan aspek perdata, tapi wilayah hukum perlindungan konsumen

11 Republik Indonesia, Undang-Undang No 8 Tahun 1999 tentang Perlindungan Konsumen, Pasal 64

12 Susanti Agung Nugroho, Proses Penyelesaian Sengketa Konsumen Ditinjau dari Hukum Acara tidak semata-mata ada dalam wilayah hukum perdata. Ada aspek-aspek hukum perlindungan konsumen yang berada dalam bidang hukum publik, terutama hukum pidana dan hukum administrasi negara. ${ }^{12}$

Ruang lingkup hukum perlindungan konsumen yang demikian luasnya, sehingga tidak tertutup kemungkinan terjadi gesekan dengan bidang-bidang hukum lainnya yang mempunyai titik taut yang erat dengan bidang hukum perlindungan konsumen ini, antara lain:

a. Bidang yang berkaitan dengan industri periklanan, yang sedang berkembang pesat di Indonesia.

b. Hukum lingkungan juga memiliki kaitan yang sangat erat dengan hukum perlindungan konsumen. Salah satu hak konsumen yang gencar diperjuangkan adalah hak mendapatkan lingkungan hidup yang bersih dan sehat.

c. Usaha-usaha pelayanan umum/publik.

d. Bidang hukum acara, khususnya dalam pembuktian, juga mempunyai keterkaitan dengan hukum perlindungan konsumen. Teori beban pembuktian terbalik, misalnya dapat menjadi alternatif yang baik untuk diakomodasikan.

e. Lembaga hukum acara yang relatif masih baru di Indonesia, seperti class action, legal standing, dan small claim menjadi bagian tak terpisahkan dalam hukum perlindungan konsumen.

f. Globalisasi produksi. Globalisasi produksi mengakibatkan terbentuknya pasar global dan konsumen global pula. Dengan demikian, aturan-aturan hukum untuk melindungi konsumen global ini membutuhkan penyesuaian dan harmonisasi dengan sistem hukum nasional.

Serta Kendala Implementasinya, (Jakarta: Kencana, 2008), hal. 72 
Dari beberapa dasar tersebut, maka hukum perlindungan konsumen dapat dibedakan menjadi ${ }^{13}$ :
a. Hukum perlindungan konsumen dalam aspek perdata
b. Hukum perlindungan konsumen dalam aspek pidana
c. Hukum perlindungan konsumen dalam aspek administrasi
d. Hukum perlindungan konsumen dalam aspek transnasional

\section{Sengketa Konsumen}

Sengketa dalam pengertian sehari-hari dimaksudkan sebagai suatu keadaan di mana pihak-pihak yang melakukan upaya-upaya perniagaan mempunyai masalah yaitu menghendaki pihak lain untuk berbuat atau tidak berbuat sesuatu tetapi pihak lainnya menolak atau tidak berlaku demikian. Sengketa juga dapat dimaksudkan sebagai adanya ketidakserasian antara pribadi-pribadi atau kelompok-kelompok yang mengadakan hubungan karena hak salah satu pihak terganggu atau dilanggar. ${ }^{14}$

Adapun mengenai pengertian dari sengketa konsumen itu sendiri menurut menteri perdagangan dalam surat keputusannya adalah:

"Yang dimaksud dengan sengketa konsumen adalah sengketa antara pelaku usaha dengan konsumen yang menuntut ganti rugi atau kerusakan, pencemaran dan/atau yang menderita kerugian akibat mengkonsumsi barang atau memanfaatkan jasa." 15

13 Sidharta, Op.Cit., hal. 16.

14 Soerjono Soekanto, Mengenai Antropologi hukum, (Bandung: Alumni, 1979), hal. 29 dalam Halim Barkatullah, Op.Cit., hal. 74.

15 Pemerintah Republik Indonesia, Surat Keputusan Menteri Perindustrian dan Perdagangan Nomor: 350/MPP/Kep/12/2001 tanggal: 10 Desember 2001.

16 Halim Barakatullah, Op.Cit., hal 77

17 Kimberly Jade Tilman, "Product Defects ResultingIn Pure Economics Loss: Under What
Maka berdasarakan uraian di atas, sengketa konsumen adalah sengketa yang terjadi antara konsumen di satu pihak dan pelaku usaha atau produsen di pihak lain. Konsumen sebagai pengguna/pemakai barang dan/atau jasa dan pelaku usaha atau produsen sebagai penyedia barang atau jasa. barang atau jasa yang dapat menjadi objek sengketa adalah produk konsumen. barang atau jasa yang dapat menjadi objek sengketa adalah produk konsumen, yaitu barang atau jasa yang umumnya digunakan konsumen untuk memenuhi kebutuhan hidupnya, keluarga, rumah tangga dan tidak untuk diperdagangkan. ${ }^{16}$

Sengketa konsumen terjadi karena adanya ketidakpuasan konsumen terhadap suatu produk atau kerugian yang dialami konsumen karena penggunaan atau pemakaian barang atau jasa. Setiap kali konsumen membeli barang, harus waspada agar tidak menderita kerugian. Menurut Kimberly Jade Tillman: "once a consumer a particular product including personal injury, injury ti the product it self some other property, and pure economic loss. " 17

Dengan demikian dapat dikatakan bahwa bentuk sengketa konsumen karena kerugian yang dapat dialami konsumen adalah:

1) Cacat tubuh/Fisik (Personal Injury)

2) Cacat Fisik (Injury to The Product it Self/Some Other Property)

3) Kerugian Ekonomi (Pure Economic Loss) ${ }^{18}$

Suatu produk dapat disebut cacat (tidak dapat memenuhi tujuan pembuatannya) ${ }^{19}$ karena:

Theory Can a Consumer Recovery, Journal pf Product Liability, Vol. 9, No. 18, USA: Pergamon Press, 1986, hlm. 276

18 Ibid

19 Jerry J. Phillips, "Product liability in a nutshell", West Publishing Co, St. Paul Minessota 1993, hal. 4, dalam AZ. Nasution, Hukum Perlindungan Konsumen, hal. 244. Hal tersebut juga dimuat juga dalam "Hak-Hak Konsumen dalam Perlindungan Konsumen.”, Agus Brotosilo, Majalah Hukum dan 
1) Cacat produk atau manufaktur

2) Cacat desain

3) Cacat peringatan atau instruksi

Cacat produk atau manufaktur adalah suatu keadaan produk yang umumnya berada di bawah tingkat harapan konsumen. Dapat pula terjadi cacat tersebut sedemikian rupa sehingga dapat membahayakan harta bendanya, kesehatan, tubuh atau jiwa konsumen. Cacat demikian dapat juga termasuk cacat desain, sebab kalau desain produk tidak terpenuhi sebagaimana mestinya, akan menimbulkan kerugian pada konsumen. ${ }^{20}$

Sedangkan cacat peringatan atau instruksi atau dapat juga disebut cacat informasi adalah cacat produk karena tidak dilengkapi dengan peringatan-peringatan tertentu atau instruksi penggunaan tertentu. Sebagai contoh adanya peringatan-peringatan tertentu atau instruksi penggunaan tertentu. Sebagai contoh adanya peringatan produk yang harus disimpan pada suhu kamar atau suhu lemari pendingin atau dapat pula peringatan agar dalam penggunaannya harus menggunakan voltage listrik tertentu dan sebagainya. $^{21}$

Produk yang tidak memuat peringatan atau instruksi tertentu yang diperlukan termasuk produk cacat yang tanggung jawabnya secara tegas dibebankan pada produsen dari produk yang bersangkutan.

Pada dewasa ini hampir semua negara dikembangkan berbagai jalan terobosan alternatif karena kelemahan penyelesaian sengketa melalui pengadilan/litigasi yang mengakibatkan terkurasnya sumber daya, dana, waktu, pikiran dan tenaga, dan mulai mengedepankan pola-pola penyelesaian sengketa di luar pengadilan. Menurut UUPK pasal 45 ayat 2 "Penyelesaian sengketa konsumen dapat ditempuh melalui pengadilan atau di luar pengadilan berdasarkan pilihan sukarela para pihak yang bersengketa". Berdasarkan ketentuan ini, bisa dikatakan bahwa ada dua bentuk penyelesaian sengketa konsumen, yaitu melalui pengadilan atau di luar jalur pengadilan.

a. Penyelesaian sengketa melalui pengadilan

Penyelesaian sengketa konsumen melalui pengadilan mengacu pada ketentuan peradilan umum yang berlaku di Indonesia.

b. Penyelesian sengketa di luar pengadilan

Penyelesaian sengketa di luar pengadilan diselenggarakan untuk mencapai kesepakatan mengenai bentuk dan besarnya ganti rugi dan/atau mengenai tindakan tertentu untuk menjamin tidak akan terjadinya kembali kerugian yang diderita konsumen.

Penyelesaian sengketa perdata di Pengadilan umumnya di dasarkan pada dua pola dasar, yaitu:

a. Adanya wanprestasi atau ingkar janji salah satu pihak,di mana untuk gugatan ini harus didasarkan adanya hubungan kontraktual (privity contract), diantara para pihak (penggugat dan tergugat);

b. Adanya perbuatan melanggar hukum(onrechtmatige daad), di mana dalam gugatan berdasarkan perbuatan melanggar hukum tidak perlu didahului adanya hubungan kontraktual di antara para pihak, namun yang paling elementer adalah adanya perbuatan yang merugikan pihak lain serta terdapat hubungan kausal antara perbuatan dan kerugian yang ditimbulkan sebagai akibat kesalahannya.

Adapun proses penyelesaian sengketa di luar pengadilan sebagaimana dimaksud pada Undang-Undang No. 18 Tahun 1999 tentang

20 Ibid., hal. 80.
21 Ibid.
Pembangunan", No. 5 Tahun XXII, hal. 434. Dalam Halim Barakatullah, Op.Cit., hal. 79. 
Perlindungan Konsumen pasal 2 tidak menghilangkan tanggung jawab pidana.

Berdasarkan ketentuan dalam UndangUndang Perlindungan Konsumen pasal 45 ayat 4, menyebutkan bahwa:

"Apabila telah dipilih upaya
penyelesaian sengketa
konsumen di luar pengadilan,
gugatan melalui pengadilan
hanya dapat ditempuh apabila
upaya tersebut dinyatakan tidak
berhasil oleh salah satu pihak
atau oleh para pihak yang
bersengketa." 22

Konsumen yang ingin menyelesaikan sengketa konsumen dengan cara nonpengadilan bisa melakukan alternatif solusi masalah (Alternative Dispute Resolution) ke Badan Lembaga Perlindungan Konsumen Swadaya Masyarakat (LPKSM), Direktorat Perlindungan Konsumen di bawah Departemen Perdagangan, atau lembagalembaga lain yang berwenang. ${ }^{23}$

Pola-pola penyelesaian sengketa di luar pengadilan yang dikehendaki UUPK, memang merupakan pilihan yang tepat karena jalan keluar yang dirumuskan berisikan penyelesaian sengketa yang memuaskan kedua belah pihak yang sedang bersengketa. Lagi pula bagi bangsa Indonesia model penyelesaian sengketa ini bukanlah hal yang baru, karena memang sudah sejak lama mengenal dan menjalankan pola-pola penyelesaian sengketa secara tradisional yang dilakukan melalui peradilan adat maupun peradilan desa (dorpsjustitie). ${ }^{24}$ Jika telah dipilih upaya penyelesaian sengketa konsumen di pengadilan, gugatan melalui pengadilan hanya dapat ditempuh jika upaya tersebut dinyatakan tidak berhasil oleh salah satu pihak yang bersengketa. Ini berarti penyelesaian

$22 \quad$ Ibid., Pasal 45 ayat 4.

23 Halim Barkatullah, Op. Cit., hal. 86

24 Susanti Agung Nugroho, Op. Cit., hal. 14.

25 Ibid., hal. 15 sengketa tetap dibuka setelah para pihak gagal menyelesaikan sengketa mereka di luar pengadilan. $^{25}$

\section{Badan Penyelesaian Sengketa Konsumen (BPSK)}

Badan Penyelesaian Sengketa

Konsumen Kota Serang terbentuk pada tahun

2010 berdasarkan Keputusan Menteri Perdagangan No. 18 Tahun 2010, sesuai dengan amanat Undang-Undang No. 8 Tahun 1999 tentang Perlindungan Konsumen yang kemudian ditegaskan dengan Keppres No. 18 Tahun 2010 tentang Pembentukan Badan Penyelesaian Sengketa Konsumen pada Kota Serang, Kota Kendari, Kota Bukittinggi, Kota Singkawang, Kota Pontianak, Kabupaten Kotawaringin Barat, Kabupaten Padang Pariaman, Kabupaten Karawang dan Kabupaten Batu Bara.

Terbentuknya Badan Penyelesaian Sengketa Konsumen Kota Serang dengan visi mewujudkan upaya penyelesaian sengketa konsumen dalam rangka pemberdayaan dan perlindungan masyarakat sehingga tercapainya peningkatan kualitas barang dan pelayanan jasa di Kota Serang dan Sekitarnya. ${ }^{26}$

Selain visi yang dalam mewujudkan pemberdayaan dan perlindungan konsumen, BPSK Kota Serang juga memiliki beberapa misi, antara lain ${ }^{27}$ :

1. Mewujudkan Kota Serang sebagai kota perdagangan dan jasa yang bermartabat sehingga memadu tercapainya peningkatan kualitas barang dan pelayanan jasa di Kota Serang dan sekitarnya.

2. Mewujudkan kemandirian dan keberdaayaan konsumen dalam mempertahankan hak dan menjalankan kewajibannya sehingga terangkat harkat dan martabatnya konsumen.

3. Mewujudkan sistem perlindungan yang mengandung unsur kepastian hukum,

26 Suharman Rahmat, SH. Badan Penyelesaian Sengketa Konsumen Kota Serang, Makalah Presentasi dalam Acara Sosialisasi Perlindungan Konsumen pada 4 Desember 2014.

27 Ibid. 
keadilan dan manfaat secara berimbang bagi konsumen dan pelaku usaha.

4. Menumbuhkan kesadaran pelaku usaha untuk bersikap jujur dan bertanggung jawab sehingga mampu menjamin kelangsungan usaha dan perlindungan konsumen.

Sejak kelahirannya BPSK Kota Serang beranggotakan 9 (sembilan) orang anggota yang terdiri dari 3 (tiga) orang unsur pemerintah, 3 (tiga) orang unsur pelaku usaha dan 3 (tiga) orang unsur konsumen serta dibantu oleh 6 (enam) orang sekretariat dari unsur pemerintah. Berkenan dengan struktur organisasi kepengurusan, anggota dan sekretariat Badan Penyelesaian Sengketa Konsumen Kota Serang bahwa untuk jabatan Ketua BPSK merupakan unsur Pemerintah adalah Suharman Rahmat, S.H. (merangkap anggota), H. Suryadi, SE sebagai wakil ketua (merangkap anggota) dan anggota lainnya dari unsur pemerintah, pengusaha dan konsumen masing-masing terdiri dari tiga orang. ${ }^{28}$ Adapun kepala Sekretariat BPSK Kota Serang berdasarkan Kepdirjen SPK No. 13/SPK/KEP/02/2012/4 adalah Sugiri, S.T., M.Si.

Badan Penyelesaian Sengketa Konsumen (BPSK) merupakan suatu lembaga khusus yang dibentuk dan diatur dalam Undang-Undang Perlindungan Konsumen, yang tugas utamanya adalah menyelesaikan sengketa atau perselisihan antara konsumen dan pelaku usaha. ${ }^{29}$ Dasar pembentukan BPSK adalah Undang-Undang No. 8 Tahun 1999 tentang Perlindungan Konsumen pasal 49 ayat (1) jo. Pasal 2 Kemenperindag No. 350/MPP/Kep/12/2001 mengatur bahwa di setiap kota atau kabupaten harus dibentuk BPSK.

Berkenaan dengan dasar hukum pembentukan Badan Penyelesaian Sengketa Konsumen Kota Serang antara lain;

28 Pemerintah Republik Indonesia, Keputusan Menteri Perdagangan Republik Indonesia No. 705/M-DAG/KEP/9/2011 tanggal 6 september 2011 tentang pengangkatan dan Anggota Badan
1. Undang-Undang No. 8 Tahun 1999 tentang Perlindungan Konsumen

2. Peraturan Menteri Perdagangan Nomor 13/M-DAG/PER/3/2010 tentang tentang pengangkatan dan Anggota Badan Penyelesaian Sengketa Konsumen Pada Pemerintah Kota Serang

3. Keputusan Presiden No. 18 Tahun 2010 tanggal 27 Agustus 2010 tentang Pembentukan Badan Penyelesaian Sengketa Konsumen pada Kota Serang, Kota Kendari, Kota Bukittinggi, Kota Singkawang, Kota Pontianak, Kabupaten Kotawaringin Barat, Kabupaten Padang Pariaman, Kabupaten Karawang dan Kabupaten Batu Bara.

4. Surat Keputusan Menteri Perdagangan Republik Indonesia No. 705/MDAG/KEP/9/2011 tanggal 6 september 2011 tentang pengangkatan dan Anggota Badan Penyelesaian Sengketa Konsumen Pada Pemerintah Kota Serang

5. Surat Keputusan Direktorat Jendral Standarisasi dan Perlindungan Konsumen Kementrian Perdagangan Republik Indonesia No. 13/SPK/KEP/02/2012 tanggal 20 Februari 2012 tentang Pengangkatan Kepala Sekretariat dan Anggota Badan Penyelesaian Sengketa Konsumen pada Pemerintah Kota Serang.

Sesuai dengan ketentuan Pasal 50 UUPK, kelembagaan BPSK terdiri dari:

a. Ketua merangkap anggota

b. Wakil ketua merangkap anggota

c. Anggota

Pada setiap BPSK dibentuk sekretariat Badan Penyelesaian Sengketa Konsumen, yang terdiri atas kepala sekretariat dan anggota yang pengangkatan dan pemberhentiannya dilakukan oleh menperindag. Selain diatur oleh Undang-Undang Perlindungan Konsumen keanggotaan BPSK juga diatur

\footnotetext{
Penyelesaian Sengketa Konsumen Pada Pemerintah Kota Serang

29 Gunawan Widjaja, Alternatif Penyelesaian Sengketa, (Jakarta: PT. Raja Grafindo Persada, 2001), hal. 73.
} 
lebih lanjut dalam Keputusan Menteri Perindustrian dan Perdagangan RI Nomor 301/MPP/Kep/10/2001 tentang Pengangkatan, Pemberhentian Anggota, dan Sekretariat Badan Penyelesaian Sengketa Konsumen.

Badan Penyelesaian Sengketa Konsumen (BPSK) merupakan suatu lembaga khusus yang dibentuk pemerintah di tiap-tiap daerah tingkat II untuk penyelesaian sengketa konsumen di luar pengadilan. ${ }^{30}$ Badan publik yang mempunyai tugas dan wewenang antara lain melaksanakan penanganan dan penyelesaian sengketa konsumen secara konsiliasi, mediasi dan arbitrase, memberikan perlindungan konsumen, melakukan pengawasan terhadap pencantuman klausula baku, melaporkan kepada penyidik umum, menerima pengaduan baik tertulis maupun tidak tertulis, memanggil pelaku usaha yang diduga telah melakukan pelanggaran, memanggil dan menghadirkan saksi serta menjatuhkan sanksi administratif terhadap pelaku usaha yang melanggar UUPK No. 8 Tahun 1999. ${ }^{31}$

Setiap penyelesaian sengketa konsumen dilakukan oleh majelis yang dibentuk oleh Ketua Badan Penyelesaian Sengketa Konsumen dan dibantu oleh Panitera. Susunan majelis BPSK harus ganjil dengan ketentuan minimal 3 orang yang mewakili semua unsur sebagaimana di maksud dalam pasal 54 ayat (2) UUPK, yaitu unsur pemerintah, konsumen, dan pelaku usaha. Salah satu anggota majelis tersebut wajib berpendidikan dan berpengetahuan di bidang hukum (pasal 18 SK Menperindag No. 350/MPP/Kep/12/2001). Ketua majelis BPSK harus dari unsur pemerintah, walaupun tidak berpendidikan hukum. Untuk menangani penyelesaian sengketa konsumen dengan cara konsiliasi atau mediasi, maka yang berwenang untuk menetapkan siapa yang menjadi personilnya baik sebagai ketua majelis yang berasal dari pemerintah maupun anggota majelis yang berasal dari unsur konsumen dan unsur pelaku usaha adalah ketua BPSK.
Hal ini berbeda dengan majelis yang akan menyelesaikan sengketa konsumen dengan cara arbitrase, ketua BPSK tidak berwenang untuk menentukan siapa yang akan menjadi ketua majelis dan anggota majelis. Yang berwenang menentukan siapa yang akan menjadi ketua majelis. Yang berwenang menentukan siapa yang yang duduk di majelis adalah para arbiter yang mewakili kepentingannya. Konsumen berhak memilih dengan bebas salah satu dari anggota BPSK yang berasal dari unsur konsumen sebagai arbiter yang akan menjadi anggota majelis. Demikian juga, pelaku usahaberhak memilih salah satu dari anggota BPSK yang berasal dari unsur pelaku usaha sebagai arbiter, yang akan menjadi anggota majelis. Selanjutnya, arbiter hasil pilihan konsumen dan arbiter hasil pilihan pelaku usaha secara bersama-sama akan memilih arbiter ketiga yang berasal dari unsur pemerintah dari anggota BPSK yang akan menjadi ketua majelis.

Prosedur untuk memilih arbiter hasil pilihan konsumen dan arbiter hasil pilihan pelaku usaha, demikian juga arbiter ketiga dariunsur pemerintah dilakukan dengan mengisi formulir pemilihan arbiter. Hasil pemilihan arbiter setelah dituangkan dalam pengisian formulir pemilihan arbiter akan ditetapkan oleh ketua BPSK sebagai majelis yang menangani sengketa konsumen dengan cara arbitrase melalui penetapan.

Panitera BPSK berasal dari anggota sekretariat yang ditetapkan oleh ketua BPSK. Tugas panitera terdiri dari:

a. Mencatat jalannya proses penyelesaian sengketa konsumen;

b. Menyimpan berkas laporan;

c. Menjaga barang bukti;

d. Membantu majelis menyusun putusan;

e. Membantu penyelesaian sengketa putusan kepada konsumen dan pelaku usaha;

f. Membuat berita acara persidangan;

g. Membantu majelis dalam tugas-tugas penyelesaian sengketa. 
Ketua majelis BPSK atau anggota BPSK atau panitera, berkewajiban untuk mengundurkan diri apabila terdapat permintaan ataupun tanpa permintaan ketua BPSK, atau anggota majelis BPSK atau pihak yang bersengketa, jika terkait hubungan keluarga sedarah atau semenda sampai derajat ketiga atau hubungan suami istri meskipun telah bercerai dengan pihak yang bersengketa.

Berkenaan dengan Pelaksanaan Tugas dan Wewenang Badan Penyelesaian Sengketa Konsumen ${ }^{32}$, sebagai berikut:

a) Melaksanakan penyelesian sengketa konsumen, dengan cara melalui mediasi atau arbitrase atau konsiliasi;

b) Memberikan konsultasi perlindungan hukum;

c) Melakukan pengawasan terhadap pencantuman klausula baku;

d) Melaporkan pengawasan terhadap penyidik umum apabila terjadi pelanggaran ketentuan dalam undangundang ini;

e) Melakukan penelitian dan pemeriksaan sengketa perlindungan konsumen;

f) Menerima pengaduan baik tertulis maupun tidak tertulis, dari konsumen tentang terjadinya pelanggaran terhadap perlindungan konsumen.

g) Memanggil pelaku usaha yang diduga telah melakukan pelanggran terhadap perlindungan konsumen;

h) Memanggil, menghadirkan saksi, saksi ahli dan/atau setiap orang yang dianggap mengetahui pelanggaran undang-undang ini;

i) Meminta bantuan penyidik untuk menghadirkan pelaku usaha, saksi, saksi ahli, atau setiap orang sebagaimana dimaksud pada huruf g dan huruf $h$, yang

32 Republik Indonesia, Undang-Undang No. 8 Tahun 1999 tentang Perlindungan Konsumen, Pasal 52 jo. Kemenperindag Nomor 350/MPP/Kep/12/2001

33 Susanti Agung Nugroho, Proses Penyelesaian Sengketa Konsumen Ditinjau dari Hukum Acara tidak bersedia memenuhi panggilan Badan Penyelesaian Sengketa Konsumen;

j) Mendapatkan, meneliti dan/atau menilai surat, dokumen, atau alat bukti lain guna penyelidikan dan/atau pemeriksaan;

k) Memutuskan dan menetapkan ada atau tidak adanya kerugian di pihak konsumen;

1) Memberitahukan putusan kepada pelaku usaha yang melakukan pelanggaran terhadap perlindungan konsumen.

m) Menjatuhkan sanksi administratif kepada pelaku usaha yang melanggar ketentuan undang-undang ini.

Berdasarkan tugas dan wewenang tersebut, maka dengan demikian terdapat 2 fungsi strategis dari Badan Penyelesaian Sengketa Konsumen, sebagai berikut ${ }^{33}$ :

a) BPSK berfungsi sebagai instrumen hukum penyelesaian sengketa di luar pengadilan (alternative dispute resolution), yaitu melalui konsiliasi, mediasi dan arbitrase.

b) Melakukan pengawasan terhadap pencantuman klausula baku (one-sided standard from contract). Termasuk di sini klausula baku yang dikeluarkan PT. PLN (Persero) di bidang kelistrikan, PT Telkom (Persero) di bidang telekomunikasi, bank-bank milik pemerintah maupun swasta, perusahaan leasing/pembiayaan dan lain-lain.

Salah satu fungsi strategis ini adalah untuk menciptakan keseimbangan kepentingan-kepentingan pelaku usaha dan konsumen. Tidak hanya klausula baku yang dikeluarkan pelaku usaha atau badan perusahaan-perusahaan swasta saja, tetapi juga pelaku usaha perusahaan-perusahaan milik negara. ${ }^{34}$

Berdasarkan ketentuan perundangundangan yang penulis uraikan, maka diketahui BPSK sebagai badan/lembaga publik selain mempunyai tugas dan

Serta Kendala Implementasinya, (Jakarta: Kencana, 2008), hal. 83.

34 Ibid., Hal. 83-84. 
kewenangan melaksanakan penanganan penyelesaian sengketa konsumen secara konsiliasi, mediasi dan arbitrase, juga memiliki kewenangan dalam memberikan konsultasi perlindungan konsumen, melakukan pengawasan terhadap pencantuman klausula baku, melaporkan kepada pencantuman klausula baku, melaporkan kepada penyidik umum, menerima pengaduan baik tertulis maupun tidak tertulis, memanggil pelaku usaha yang diduga telah melakukan pelanggaran, memanggil dan menghadirkan saksi serta menjatuhkan sanksi administratif terhadap pelaku usaha yang melanggar UUPK ini.

Badan Penyelesaian Sengketa Konsumen dibentuk agar penyelesaian sengketa dapat diselesaikan dengan cara mudah, cepat dan murah. Cepat karena undang-undang menentukan dalam tenggang waktu 21 hari kerja, BPSK wajib memberikan putusannya. ${ }^{35}$ Murah terletak pada biaya perkara yang terjangkau. Setiap konsumen yang merasa dirugikan pelaku usaha dapat mengadukan masalahnya kepada BPSK, baik secara langsung, diwakili kuasanya maupun oleh ahli warisnya. Pengaduan yang disampaikan oleh kuasanya atau ahli warisnya hanya dapat dilakukan apabila konsumen dalam keadaan sakit, meninggal dunia, lanjut usia, belum dewasa atau bukan warga negara asing.

Pada prinsipnya penyelesaian sengketa konsumen diusahakan dapat dilakukan secara damai, sehingga dapat memuaskan para pihak yang bersengketa (win-win solution). Menurut Leo Kanowittz, penyelesaian sengketa di pengadilan mempunyai kadar keterikatan kepada aturan main yang bervariasi, dari yang paling kaku dalam menjalankan aturan main sampai kepada yang paling relaks. ${ }^{36}$

35 Yusuf Sofi dan Somi Awan, Sosok Peradilan Konsumen Mengungkap Berbagai Persoalan Mendasar BPSK, (Jakarta: Piramedia, 2004), hal. 17.
Selanjutnya dikemukakan bahwa tidak semua model penyelesaian sengketa di luar pengadilan/alternatif baik untuk para pihak yang bersengketa. Suatu penyelesaian sengketa alternatif yang baik setidak-tidaknya haruslah memenuhi prinsip sebagai berikut:

1) Haruslah efisien dari segi waktu;

2) Haruslah hemat biaya;

3) Haruslah melindungi hak-hak dari para pihak yang bersengketa;

4) Haruslah dapat menghasilkan putusan yang adil dan jujur;

5) Badan atau orang yang menyelesaiakan sengketa haruslah terpercaya di masyarakat dan para pihak yang bersengketa;

6) Putusannya harus final dan mengikat;

7) Putusannya haruslah dapat dan mudah dieksekusi;

8) Putusannya haruslah sesuai dengan perasaan keadilan dari komunitas di mana penyelesaian sengketa dilaksanakan.

Tata cara penyelesaian sengketa konsumen diatur dalam Undang-Undang No. 8 Tahun 1999 jo. Kemenperindag No. 350/MPP/12/2001 tentang Pelaksanaan Tugas dan Wewenang Badan Penyelesaian Sengketa Konsumen. Proses penyelesiannyapun diatur sangat sederhana dan sejauh mungkin dihindari dari suasana yang formal. UUPK menentukan apabila telah dipilih upaya penyelesaian sengketa konsumen di luar pengadilan, gugatan melalui pengadilan hanya dapat ditempuh apabila upaya tersebut dinyatakan tidak berhasil oleh salah satu pihak yang bersengketa.

Beberapa tahapan dalam pengajuan gugatan sampai pada tahap keputusan dan eksekusi putusan akan dijelaskan sebagai berikut:

36 Leo Kanowitz, Alternative Dispute Resolution, (Minessota USA: St. Paul, 1985), hal. 6, dalam Susanti Agung, Op.Cit., hal. 100. 
1. Tahap pengajuan gugatan

Konsumen yang dirugikan dapat mengajukan permohonan penyelesaian sengketa konsumen kepada BPSK yang terdekat dengan tempat tinggal konsumen. Permohonan dapat dilakukan oleh konsumen sendiri atau kuasanya atau ahli waris yang bersangkutan jika konsumen telah meninggal dunia, sakit atau telah lanjut usia sehingga tidak dapat mengajukan pengaduan sendiri baik secara tertulis maupun lisan, sesuai dengan ketentuan perundang-undangan yang berlaku terhadap orang asing/warga negara asing.

Permohonan diajukan secara tertulis, kepada sekretariat BPSK, maka sekretariat BPSK akan memberikan tanda terima kepada pemohon, dan jika permohonan diajukan secara lisan, maka sekretariat BPSK akan mencatat permohonan tersebut dalam sebuah formulir yang disediakan secara khusus, dibubuhi tanggal dan nomor registrasi. Apabila permohonan ternyata tidak lengkap (tidak sesuai dengan pasal 16 Kemenperindag

No.350/MPP/Kep/12/2001) atau permohonan bukan merupakan kewenangan BPSK, maka ketua BPSK menolak permohonan tersebut. Jika permohonan memenuhi persyaratan dan diterima, maka ketua BPSK harus memnaggil pelaku usaha secara tertulis disertai dengan kopi permohonan dari konsumen, selambat-lambatnya 3 hari kerja sejak diterimanya permohonan.

Untuk keperluan pemanggilan pelaku usaha, dibuat surat panggilan yang memuat hari, tanggal, jam dan tempat persidangan serta kewajiban pelaku usaha untuk memberikan jawaban terhadap

37 Setiap penyelesaian sengketa oleh BPSK dilakukan oleh Majelis yang dibentuk berdasarkan penetapan Ketua BPSK dan dibantu oleh panitera. Majelis tersebut harus berjumlah ganjil dan paling sedikit terdiri dari 3 anggota BPSK yang mewakili penyelesaian sengketa konsumen untuk diajukan pada persidangan pertama.

Jika pada hari yang ditentukan pelaku usaha tidak hadir memenuhi panggilan, maka sebelum melampaui 3 hari kerja sejak pengaduan, pelaku usaha dapat dipanggil sekali lagi. Jika pelaku usahasekali lagi tidak hadir tanpa alasan yang sah, maka BPSK dapat meminta bantuan penyidik untuk menghadirkan pelaku usaha tersebut.

Jika pelaku usaha hadir, maka konsumen memilih cara penyelesaian sengketanya harus disetujui pelaku usaha. Cara yang bisa dipilih dan disepakati para pihak adalah konsiliasi, mediasi dan arbitrase. Jika cara yang dipilih para pihak adalah konsiliasi dan mediasi, maka ketua BPSK segera menunjuk majelis sesuai dengan ketentuan untuk ditetapkan sebagai konsiliator atau mediator. Jika yang dipilih para pihak adalah arbitrase, maka ketentuannya para pihak memilih arbiter dari anggota BPSK yang berasal dari unsur pelaku usaha dan konsumen sebagai anggota majelis. Arbiter yang terpilih memilih arbiter ketiga dari anggota BPSK yang berasal dari unsur pemerintah sebagai ketua majelis. ${ }^{37}$ Persidangan pertama dilaksanakan selambat-lambatnya hari kerja ke-7 terhitung diterimanya permohonan.

2. Tahap persidangan

Pada penyelesaian sengketa melalui konsiliasi ini, majelis BPSK sebagai konsiliator memanggil konsumen dan pelaku usaha yang bersengketa, dan memanggil saksisaksi beserta saksi ahli, dan bila diperlukan menyediaan forum konsiliasi bagi konsumen dan pelaku usaha yang bersengketa dan menjawab

unsur pemerintah (sebagai ketua) dan unsur konsumen dan pelaku usaha masing-masing sebagai anggota. Sedangkan panitera ditunjuk dari anggota sekretariat BPSK. 
pertanyaan konsumen dan pelaku usaha, perihal peraturan perundangundangan di bidang perlindungan konsumen.

Hasil musyawarah yang merupakan kesepakatan antara konsumen dan pelaku usaha yang bersengketa selanjutnya dibuat dalam bentuk perjanjian tertulis yang ditanda tangani oleh para pihak yang bersengketa dan diserahkan kepada majelis untuk dituangkan dalam keputusan majelis BPSK yang menguatkan perjanjian tersebut.

Di setiap tingkat dalam proses konsiliasi, konsiliator dapat mengajukan proposal penyelesaian sengketa. Konsiliator dapat melakukan proses konsiliasi yang dianggapnya layak, dengan mempertimbangkan faktor-faktor antara lain sebagai berikut:

a) Situasi dan kondisi dari kasus tersebut;

b) Keinginan para pihak, termasuk keinginan yang diucapkan para pihak secara lisan; dan

c) Kebutuhan untuk diproses cepat.

Penyelesaian sengketa melalui mediasi dilakukan sendiri oleh para pihak yang bersengketa dengan didampingi mediator. Mediator menyerahkan sepenuhnya proses penyelesaian sengketa kepada para pihak, baik mengenai bentuk maupun besarnya ganti rugi atau tindakan tertentu untuk menjamin tidak terulangnya kembali kerugian konsumen. Dibandingkan dengan proses penyelesaian sengketa melalui konsiliasi, dalam proses mediasi ini, mediator bertindak lebih aktif dengan memberikan nasihat, petunjuk saran

38 Frans Hendra Winarta, Hukum Penyelesaian Sengketa, Arbitrase Nasional dan Internasional, ( Jakarta: Sinar Grafika, 2011), hal. 16. dan upaya-upaya lain dalam menyelesaikan sengketa.

Beberapa prinsip mediasi adalah bersifat sukarela atau tunduk pada kesepakatan para pihak, pada bidang perdata, sederhana, tertutup dan rahasia, serta bersifat menengahi atau bersifat sebagai fasilitator. ${ }^{38}$ Mediator wajib menentukan jadwal pertemuan untuk penyelesaian proses mediasi. Apabila dianggap perlu, mediator bisa melakukan permediasian antara konsumen dan pelaku usaha secara terpisah (kaukus). Pengalaman dan kemampuan mediator diharapkan dapat mengefektifkan mediasi di antara para pihak yang bersengketa.

Dalam proses mediasi ini mediator harus mampu berperan sebagai berikut ${ }^{39}$ :

a. Mendekatkan persamaan kepentingan dan meminimalkan perbedaan kepentingan;

b. Menciptakan pertemuan yang kondusif, akrab dan terarah (fokus) pada substansi masalah;

c. Tidak mempromosikan diri sebagai orang yang memutuskan dan tidak menilai benar atau salah;

d. Mendiagnosa substansi masalah mengidentifikasi masalah dan kemungkinan solusi yang dapat diterima oleh para pihak;

e. Menawarkan usulan atau pilihan yang dapat diterima oleh para pihak;

f. Menawarkan usulan atau pilihan pemecahan masalah kepada para pihak;

g. Turut membantu pelaksanaan akta kompromi yang dihasilkan.

Seperti halnya dalam konsiliasi, proses mediasi ini atas permintaan para pihak, mediator dapat meminta bukti

39

Candra Irawan, Aspek Hukum dan Mekanisme Penyelesaian Sengketa di Luar Pengadilan (Alternative Dispute Resolution), (Bandung: Mandar Maju, 2010), hal. 44. 
baik surat dan/atau dokumen lain, yang mendukung kedua belah pihak. Atas persetujuan para pihak atau kuasanya, mediator dapat mengundang seorang atau lebih saksi atau saksi ahli dalam bidang tertentu untuk memberikan penjelasan mengenai hal-hal terkait dengan sengketanya. Jika proses mediasi menghasilkan kesepakatan, para pihak dengan bantuan mediator wajib merumuskan secara tertulis kesepakatan yang dicapai dan ditanda tangani oleh para pihak.

Peran majelis BPSK dalam penyelesaian sengketa konsumen dengan cara mediasi secara deskriptif, meliputi sebagai berikut:

a) Memanggil konsumen dan pelaku usaha yang bersengketa;

b) Memanggil saksi dan saksi ahli apabila diperlukan;

c) Menyediakan forum bagi konsumen dan pelaku usaha yang bersengketa;

d) Secara aktif mendamaikan kedua belah pihak yang bersengketa;

e) Secara aktif memberikan saran atau anjuran penyelesaian sengketa konsumen sesuai dengan peraturan perundang-undangan di bidang perlindungan konsumen.

Hasil musyawarah yang merupakan kesepakatan bersama antara konsumen dan pelaku usaha yang bersengketa, selanjutnya dibuat dalam bentuk perjanjian tertulis, yang ditanda tangani oleh para pihak yang bersengketa dan diserahkan kepada majelis BPSK untuk menguatkan perjanjian tersebut. Putusan tersebut mengikat kedua belah pihak. Keputusan majelis dalam konsiliasi dan mediasi tidak memuat sanksi administratif.

40 Republik Indonesia, Undang-Undang No. 39 Tahun 1999 tentang Arbitrase

41 Susanti Agung Nugraha, Op. Cit., hal. 114.
Arbitrase adalah salah satu bentuk adjustifikasi privat. Di dalam uu arbitrasee pengertian arbitrase adalah "cara penyelesaian suatu perkara sengketa perdata di luar pengadilan, yang didasarkan pada perjanjian arbitrase yang dibuat secara tertulis oleh para pihak yang bersengketa." 40 Arbitrase sebagai salah satu lembaga alternatif penyelesaian sengketa paling formal untuk penyelesaian sengketa sebelum berlitigasi. Dalam proses perkara ini pihak bersengketa mengemukakan masalah mereka kepada pihak ketiga yang netral dan memberinya wewenang untuk mengambil keputusan. $^{41}$

Berdasarkan pengertian tersebut, hanya perkara perdata saja yang dapat diselesaikan dan diputuskan oleh lembaga arbitrase sebagaimana dimaksud dalam undang-undang arbitrase adalah suatu kesepakatan berupa klausula arbitrase yang tercantum dalam suatu perjanjian tertulis yang dibuat para pihak sebelum timbul sengketa atau suatu perjanjian arbitrase tersendiri yang dibuat para pihak setelah timbul sengketa. $^{42}$

Bila dibandingkan dengan proses penyelesaian sengketa melalui lembaga peradilan, maka lembaga arbitrase mempunyai beberapa kelebihan antara lain:

a) Dijamin kerahasiaan sengketa para pihak

b) Dapat dihindari keterlambatan yang diakibatkan karena hal prosedural dan adminstratif.

c) Para pihak dapat memilih arbiter yang menurut keyakinannya mempunyai pengetahuan, pengalaman, serta latar belakang

42 Republik Indonesia, Undang-Undang No. 39 Tahun 1999 tentang Arbitrase, Pasal 1 Butir 3 
yang cukup mengenal masalah yang disengketatkan, juur dan adil;

d) Para pihak dapat menentukan pilihan hukum untuk menyelesaiakan masalahnya serta proses dan tempat penyelenggaraaan arbitrase;

e) Putusan arbitrase merupakan putusan yang mengikat para pihak dan dengan melalui tata cara yang sederhana dan langsung dapat dilaksanakan.

Penyelesaian sengketa melalui arbitrase, para pihak memilih arbiter dari anggota BPSK yang berasal dari unsur pelaku usaha dan konsumen sebagai anggota mejelis. Arbitor yang dipilih oleh para pihak kemudian memilih arbitor ketiga dari anggota BPSK yang berasal dari unsur pemerintah sebagai ketua. $^{43}$ Pada persidangan pertama ketua majelis wajib membuat putusan dalam bentuk penetapan perdamaian. ${ }^{44}$ Sebaliknya jika tidak tercapai perdamaian maka persidangan dimulai dengan membacakan isi gugatan konsumen, dan surat jawaban dari pelaku usaha. Ketua majelis BPSK harus memberikan kesempatan yang sama kepada kedua belah pihak yang bersengketa untuk menjelaskan hal-hal yang dipersengketakan. ${ }^{45}$

Pada persidangan pertama sebelum pembacaan surat jawaban dari pelaku usaha, konsumen dapat mencabut gugatannya dengan membuat surat pernyataan pencabutan perkara. Dalam hal demikian, maka majelis wajib mengumumkan bahwa gugatan dicabut. ${ }^{46}$ Apabila pelaku usaha dan/atau konsumen tidak hadir

43 Pemerintah Republik Indonesia, Keputusan Menteri Perindustrian dan Perdagangan No.350/MPP/Kep/12/2001, Pasal 35 Ayat (3)

$44 \quad$ Ibid., Pasal 35 Ayat (3).

45 Ibid., Pasal 34.

$46 \quad$ Ibid., Pasal 35 Ayat (1) dan (2) dalam persidangan pertam maka majelis memberikan kesempatan terakhir pada persidangan kedua dengan membawa alat bukti yang diperlukan. Persidangan kedua diselenggarakan selambat-lambatnya dalam waktu 5 hari kerja terhitung sejak persidangan pertama dan diberitahukan kepada konsumen dan pelaku usaha, dengan surat panggilan oleh sekretariat BPSK. Bilamana pada persidangan kedua belah pihak tidak hadir maka gugatannya dinyatakan gugur demi hukum. Sebaliknya, jika pelaku usaha yang tidak hadir, maka gugatan konsumen dikabulkan oleh majelis tanpa kehadiran pelaku usaha. ${ }^{47}$

Selama proses penyelesaian sengketa, alat-alat bukti barang atau jasa, surat dan dokumen keterangan para pihak, keterangan saksi dan/atau saksi ahli, dan bukti-bukti lain yang mendukung dapat diajukan kepada majelis. Dalam proses penyelesaian sengketa konsumen oleh BPSK beban pembuktian ada pada pelaku usaha, namun pihak konsumen juga harus mengajukan bukti-bukti untuk mendukung gugatannya. Setelah mempertimbangkan pernyataan dari kedua belah pihak mengenai hal yang dipersengketakan dan mempertimbangkan hasil pembuktian serta permohonan yang diinginkan para pihak, maka majelis BPSK memberikan putusan.

3. Tahap putusan

Putusan Majelis BPSK dapat dibedakan atas dua jenis putusan ${ }^{48}$, yaitu:

$47 \quad$ Ibid., Pasal 36 Ayat (3)

48 Aman Sinaga, Peran dan Fungsi Badan Penyelesaian Sengketa Konsumen dalam Upaya Perlindungan Konsumen, (Makalah yang disampaikan dalam rangka sosialisasi UUPK yang 
a) Putusan BPSK dengan cara konsiliasi dan mediasi

Putusan dengan cara konsiliasi dan mediasi pada dasarnya hanya mengukuhkan isi perjanjian perdamaian, yang telah disetujui dan ditandatangani oleh kedua belah pihak yang bersengketa.

b) Putusan BPSK dengan cara arbitrase Putusan BPSK dengan cara arbitrase seperti halnya putusan perkara perdata, memuat duduknya perkara dan pertimbangan hukumnya.

Putusan majelis BPSK sedapat mungkin didasarkan atas musyawarah untuk mencapai mufakat, namun jika telah diusahakan sungguh-sungguh ternyata tidak berhasil kata mufakat, maka putusan diambil dengan suara terbanyak (voting). ${ }^{49}$ Hasil penyelesaian sengketa konsumen dengan cara konsiliasi atau dengan cara mediasi dibuat dalam perjanjian tertulis yang ditandatangani oleh konsumen dan pelaku usaha, selanjutnya dikuatkan dengan putusan majelis.

Keputusan mejelis dalam konsiliasi dan mediasi tidak memuat sanksi administratif, sedangkan hasil penyelesaian sengketa konsumen dengan cara arbitrase dibuat dengan putusan majelis yang ditandatangani oleh ketua dan anggota majelis. Keputusan majelis dalam arbitrase dapat memuat sanksi administratif. ${ }^{50}$ Putusan BPSK dapat berupa perdamaian, gugatan ditolak atau gugatan dikabulkan. Pelaku usaha bertanggung jawab memberikan ganti kerugian atas kerusakan, pencemaran akibat mengonsumsi barang yang diperdagangkan, dan/atau kerugian konsumen atas jasa yang dihasilkan. ${ }^{51}$ Manakala gugatan dikabulkan maka dalam amar putusan

diselenggarakan oleh PIRAC, 2004), hal. 6. Dalam Susanti Agung., Op.Cit., hal. 119.

49 Pemerintah Republik Indonesia, Keputusan Menteri Perindustrian dan Perdagangan No.350/MPP/Kep/12/2001, Pasal 39.

$50 \quad$ Ibid., Pasal 37 Ayat (5) ditetapkan kewajiban yang harus dilakukan oleh pelaku usaha dapat berupa pemenuhan:

(1) Ganti kerugian sebagaimana dimaksud dalam putusan

Bentuk ganti kerugian tersebut dapat berupa ${ }^{52}$ :

(a) Pengembalian uang atau penggantian barang dan/atau jasa yang sejenis atau setara nilainya atau perwatannya.

(b) Pemberian santunan sesuai dengan ketentuan peraturan perundangundangan yang berlaku.

(c) Ganti kerugian tersebut dapat pula ditujukan sebagai penggantian kerugian terhadap keuntungan yang akan diperoleh apabila tidak terjadi kecelakaan, atau kehilangan pekerjaan atau penghasilan untuk sementara atau seumur hidup akibat kerugian fisik yang diderita, dan sebagainya.

(2) Sanksi adminstratif berupa penetapan ganti kerugian paling banyak Rp. 200.000.000,- (dua ratus juta rupiah).

Sanksi administratif dapat dibebankan kepada pelaku usaha yang melakukan pelanggaran terhadap ${ }^{53}$ :

(a) Tidak dilaksanakannya pemberian ganti kerugian oleh pelaku usaha kepada konsumen, dalam bentuk pengembalian uang atau penggantian barang atau jasa yang sejenis, maupun perawatan kesehatan atau pemberian santunan atas kerugian yang diderita konsumen;

(b) Terjadinya kerugian sebagai akibat kegiatan produksi iklan yang dilakukan oleh pelaku usaha periklanan;

51 Republik Indonesia, Undang-Undang No. 8 Tahun 1999 tentang Perlindungan Konsumen, Pasal 19 Ayat (1).

$52 \quad$ Ibid., Pasal 19 Ayat (2)

53 Republik Indonesia, Undang-Undang No. 8 Tahun 1999 tentang Perlindungan Konsumen, Pasal 19 Ayat (4). 
(c) Pelaku usaha yang tidak dapat menyediakan fasilitas jaminan purna-jual, baik dalam bentuk suku cadang maupun pemeliharaannya, serta pemberian jaminan garansi yang telah ditetapkan sebelumnya. Ketentuan ini berlaku baik terhadap pelaku usaha yang memperdagangkan barang atau jasa.

Gugatan kerugian secara perdata, tidak menutup kemungkinan adanya tuntuntan pidana berdasarkan pembuktian lebih lanjut mengenai adanya unsur kesalahan dari pelaku usaha. Ganti kerugian yang dapat digugat oleh konsumen maupun yang dapat dikabulkan BPSK adalah ganti kerugian yang nyata/riil yang dialami konsumen. UUPK tidak mengenal gugatan immateriil, yaitu gugatan ganti kerugian atas hilangnya kesempatan untuk mendapatkan keuntungan, kenikmatan, nama baik dan sebagainya. Oleh sebab itu, majelis BPSK dilarang mengabulkan gugatan immateriil yang diajukan konsumen. Sebaliknya dalam upaya melindungi konsumen, UUPK memberi wewenang kepada BPSK untuk menjatuhkan sanksi administratif yang dibebankan kepada pelaku usaha untuk dibayarkan kepada konsumen.

Ganti kerugian berupa sanksi administratif adalah berbeda dengan ganti kerugian yang nyata atau riil yang dialami konsumen yang digugat melalui BPSK. Majelis BPSK selain mengabulkan gugatan ganti kerugian nyata dialami konsumen juga berwenang menambahkan ganti kerugian berdasarkan sanksi administratif tersebut. Besarnya ganti kerugian tersebut tergantung pada nilai kerugian konsumen akibat memakai, menggunakan, atau memanfaatkan barang atau jasa produsen atau pelaku usaha. ${ }^{54}$ $\quad \begin{gathered}\text { Perlu diperhatikan } \\ \text { sesuai dengan } \\ \text { Ketentuan }\end{gathered}$
No.350/MPP/Ken/12/2001, BPSK berwenang

$54 \quad$ Susanti Agung, Op. Cit., hal. 121.

55 Pemerintah Republik Indonesia, Keputusan Menteri Perindustrian dan Perdagangan menjatuhkan ganti kerugian berdasarkan sanksi administratif ini, hanya dapat dibebankan kepada pelaku usaha jika penyelesaian sengketanya dilakukan dengan arbitrase saja. Hal ini dapat dimengerti karena putusan BPSK dengan cara konsiliasi atau mediasi semat-mata dijatuhkan berdasarkan surat perjanjian perdamaian yang dibuat dan ditandatangani oleh kedua belah pihak yang bersengketa, sehingga ganti kerugian berdasarkan sanksi administratif tidak diperlukan. ${ }^{55}$

Majelis wajib memutuskan sengketa konsumen tersebut selambat-lambatnya dalam waktu 21 hari kerja terhitung sejak gugatan diterima BPSK. ${ }^{56}$ Setelah putusan BPSK diberitahukan, selambat-lambatnya dalam waktu 7 hari kerja sejak putusan dibacakan, konsumen dan/atau pelaku usaha yang bersengketa wajib menyatakan menerima atau menolak putusan BPSK. Apabila konsumen dan/atau pelaku usaha menolak putusan BPSK, maka mereka dapat mengajukan keberatan selambat-lambatnya dalam waktu 14 hari kerja terhitung sejak putusan BPSK diberitahukan. Sebaliknya apabila konsumen dan pelaku usaha menerima putusan BPSK, maka pelaku usaha wajib menjalankan putusan tersebut selambat-lambatnya dalam waktu 7 hari kerja sejak menyatakan menerima putusan tersebut.

Putusan BPSK yang tidak diajukan keberatan oleh pelaku usaha, dimintakan penetapan fiat eksekusinya pada pengadilan negeri di tempat tinggal konsumen yang dirugikan. Pelaku usaha yang menolak putusan BPSK, tetapi tidak mengajukan keberatan setelah sampai batas waktu untuk menjalankan putusan dianggap menerima putusan. Apabila selambat-lambatnya 5 hari kerja setelah batas waktu mengajukan keberatan dilampaui, pelaku usaha tidak menjalankan kewajiban sebagaimana tertuang dalam putusan BPSK, maka BPSK menyerahkan putusan tersebut kepada penyidik untuk dilakukan penyidikan

No.350/MPP/Kep/12/2001, Pasal 37 Ayat (1) dan (2).

$56 \quad$ Ibid., Pasal 38. 
sesuai dengan ketentuan perundang-undangan yang berlaku. ${ }^{57}$

Putusan BPSK merupakan putusan final dan mempunyai kekuatan hukum yang tetap. Terhadap putusan BPSK ini, dapat dimintakan eksekusi oleh BPSK kepada Pengadilan Negeri ditempat konsumen yang dirugikan. Mengacu pada ketentuan Pasal 54 Ayat (3) UUPK maupun pasal 42 (1) Keputusan Menteri Perindustrian dan Perdagangan No.350/MPP/Kep/12/2001 tersebut, putusan BPSK adalah final dan mengikat dan tidak dimungkinkan lagi untuk mengajukan banding atau keberatan. Sebaliknya Pasal 56 Ayat (2) UUPK masih dibuka peluang untuk mengajukan keberatan kepada pengadilan negeri, dalam tenggang waktu 14 hari setelah putusan BPSK diberitahukan. Permasalahan timbul karena UUPK tidak menegaskan secara limitatif luas lingkup adanya keberatan terhadap putusan BPSK. ${ }^{58}$

Dalam sistem peradilan di negara ini, implementasi instrumen hukum keberatan ini membingungkan dan menimbulkan berbagai persepsi, terutama para hakim, manakala tidak ada panduan yang jelas dan konsisten terhadap penafsiran undang-undang, apalagi jika pedoman untuk melaksanakan undang-undang tersebut tidak tersedia di pengadilan. Oleh karena itu, timbul disparitas putusan terhadap suatu sengketa konsumen yang pada dasarnya merupakan suatu upaya keberatan terhadap putusan BPSK, yang mengakibatkan pada dewasa ini, dalam implementasinya tidak konsistensi dan kesatuan pendapat dari berbagai putusan pengadilan.

\section{PENUTUP}

\section{SIMPULAN}

Penyelesaian sengketa konsumen di Badan Penyelesaian Sengketa Konsumen (BPSK) Kota Serang merupakan alternatif penyelesaian sengketa di luar pengadilan dengan asas cepat, sederhana dan biaya murah yang cara penyelesaian sengketanya ditempuh menggunakan salah satu metode penyelesaian sengketa baik secara konsiliasi, mediasi maupun arbitrase atas dasar pilihan dan persetujuan para pihak yang bersengketa sebagaimana ketentuan dalam UndangUndang No. 8 Tahun 1999 tentang Perlindungan Konsumen. Putusan yang dikeluarkan oleh Badan Penyelesaian Sengketa Konsumen (BPSK) Kota Serang merupakan putusan yang bersifat final dan mengikat meskipun masih dibukanya upaya keberatan yang diajukan ke Pengadilan Negeri setempat oleh pihak yang tidak menerima putusan BPSK yang diputus dengan cara arbitrase. BPSK sebagai lembaga yang berwenang menyelesaikan sengketa konsumen di luar jalur pengadilan hanya dinilai dari persepsi administratif saja dan putusan BPSK tersebut dinilai bukan produk badan peradilan mengingat kedudukan BPSK yang secara struktural berada di bawah kementrian Perdagangan yang tidak termasuk lembaga peradilan, sehingga dalam pelaksanaan putusan BPSK yang diputus secara arbitrase harus dimintakan fiat eksekusi ke Pengadilan Negeri setempat. Permohonan eksekusi ke Pengadilan Negeri ditempuh karena pengadilan negeri sebagai lembaga yudisial memiliki sarana untuk eksekusi karena memang memiliki juru sita yang memang ditugaskan untuk eksekusi.

\section{SARAN}

1. Membentuk BPSK di setiap kabupaten/kota di seluruh Indonesia agar upaya perlindungan konsumen dapat berjalan lebih baik dan tidak terbebaninya APBD di BPSK kabupaten/kota atas pengaduan masyarakat di luar kabupaten/kota tersebut.

2. Perampingan tugas BPSK yang menjalankan multi peran yang kompleks dalam penegakan hukum perlindungan konsumen menjadi sebatas badan yang berwenang menyelesaikan sengketa konsumen sesuai dengan namanya agar

58 Susanti Agung Nugroho, Op.Cit., Hal. 124. 
BPSK benar-benar fokus dalam melaksanakan tugasnya dengan baik.

3. Dibuatnya peraturan yang memberikan batasan yang jelas tentang kompetensi dan syarat-syarat keanggotaan BPSK.

\section{DAFTAR PUSTAKA}

Abdul Halim Barakatullah. Hak-Hak Konsumen. Bandung: Nusa Media, 2010.

Adrian Sutedi. Hak Tanggungan dalam Teori dan Praktik. Jakarta: Sinar Grafika, 2009.

Agus Yudha Hernoko. Hukum perjanjian; Asas Proporsionalitas dalam Kontrak Komersial. Jakarta: Kencana, 2010.

Ahmadi Miru. Prinsip-Prinsip Perlindungan Hukum Bagi Konsumen di Indonesia. Surabaya Airlangga, 2000.

AZ Nasution. Hukum Perlindungan Konsumen: Suatu Pengantar. Cetakan Keempat. Jakarta: Diadit Medika, 2011.

Frans Hendra Winarta. Hukum Penyelesaian Sengketa: Arbitrase Nasional dan Internasional. Edisi Kedua. Jakarta: Sinar Grafika, 2012.

Gunawan Widjaya dan Ahmad Yani. Hukum Tentang Perlindungan Konsumen. Jakarta: Pustaka Gramedia Utama, 2003.

Jimly Asshidiqie. Hukum Tata Negara \& Pilar-Pilar Demokrasi. Jakarta: Sinar Grafika, 2012.

,Konstitusi \& Konstitusionalisme Indonesia. Jakarta: Sekretariat Jenderal dan Kepaniteraan Mahkamah Konstitusi Republik Indonesia, 2005

Kartini Muljadi \& Gunawan Widjaya. Perikatan pada Umumnya. Cetakan Kedua. Jakarta: PT. Raja Grafindo Persada, 2004.

Lili Rasjidi dan I.B Wiyasa Putra. Hukum Sebagai Suatu Sistem. Bandung: Remaja Rusdakarya, 1993.
Miriam Budiarjo. Dasar-Dasar Ilmu Politik. Jakarta: PT. Gramedia:, 1983.

Munir Fuady. Teori Negara Hukum Modern (Rechstaat). Bandung: Refika Aditama, 2009.

$\longrightarrow$ Arbitrase Nasional: Alternatif Penyelesaian sengketa Bisnis, Bandung: PT. Citra Aditya Bakti, 2000.

Nurnaningsih Amriani. Mediasi: Alternatif Penyelesaian Sengketa Perdata di Pengadilan. Jakarta: PT. Raja Grafindo Persada, 2011.

R. Subekti. Aneka Perjanjian. Bandung: Penerbit Alumni, 1987.

Retnowulan Sutartio, Hukum Acara Perdata: dalam Teori dan Praktek. Bandung: Mandar Maju, 2009.

Salim HS. Hukum Kontrak: Teori \& Teknik Penyusunan Kontrak. Cetakan kesembilan. Jakarta: Sinar Grafika, 2013.

Susanti Agung Nugroho. Proses Penyelesaian Sengketa Konsumen Ditinjau dari Hukum Acara Serta Kendala Implementasinya. Jakarta: Kencana, 2008.

Syahrizal Abbas. Mediasi: Dalam Hukum Syariah, Hukum Adat dan Hukum Nasional. Edisi Kesatu. Cetakan Kedua. Jakarta: Kencana, 2011.

Syahmin AK. Hukum Kontrak Internasional. Jakarta: PT. Raja Grafindo Persada, 2006.

Tutik Wulandari Tatik. Hukum Perlindungan Konsumen di Indonesia. Bandung: Penerbit Alumni, 2010. 
AJUDIKASI : Jurnal Ilmu Hukum, Vol. 2 No. 1, Juni 2018. Hlm 21-42 